\title{
ISSN:
}

Print - $2277-0755$

Online - $2315-7453$

(C) FUNAAB 2020

\author{
Journal of \\ Agricultural \\ Science \\ and Environment
}

\section{ENTERPRISE ASSESSMENT ACROSS CASSAVA WASTE (PEELS) VALUE CHAIN IN OGUN STATE}

\author{
V. A. ELEGBEDE, E. O. A. OLUWALANA AND A. M. SHITTU
}

Department of Agricultural Economics and Farm Management, Federal University of Agriculture, Abeokuta, Nigeria

*Corresponding Author: asikavivian@yahoo.com ～Tel: +23460156956

\begin{abstract}
In this article, the Enterprise assessment across cassava peels value chain in Ogun State Nigeria is examined. Multistage sampling technique was used to select 180 cassava processors and marketers. Socio-economic data were obtained from respondents with the use of pre-tested questionnaires. Data were analysed using descriptive statistics, budgetary technique, Stochastic Frontier Analysis (SFA) and Student t-test. The study found that majority ( $84.3 \%$ and $52.8 \%$ ) of processors of cassava peels and marketers were female. In addition, $60.2 \%$ of the processors and $51.4 \%$ of the marketers had secondary education. The value chain activities carried out by processors were transportation, drying and packaging while marketers transported, packaged and put the peels in storage for future sales. The SFA revealed that cost of labour $(p<0.01)$ and quantity of fresh cassava peels $(p<0.01)$ were the main determinants of output of dried cassava peels by the processors. The inefficiency model revealed that the efficiency of producing dried cassava peels increased with increase in age $(p<0.01)$, credit access $(p<0.01)$, household size $(p<0.01)$ and membership of cooperative society $(p<0.01)$. Furthermore, the cost function revealed that cost of sieving $(p<0.05)$ and depreciation on capital item $(p<0.01)$ increased the production cost of dried cassava peels. The mean technical, allocative and economic efficiency of producing dried cassava peels were estimated as $94 \%, 83 \%$ and $78 \%$ respectively. This study concluded that production of cassava peels is efficient and its trade is profitable. The study recommends that cassava processors and marketers should form cooperative groups to increase access to credit for higher output and trade of peels.
\end{abstract}

Keywords; cassava peels, value chain, marketers, gross margin, processors, efficiency.

\section{INTRODUCTION}

Despite the role of cassava in the economy of Nigeria, there is need to increase the value addition mechanism by improving the quality of cassava products being produced in Nigeria, as well as the processing equipment for the country to benefit from the high demand of cassava products presently both at domestic and international levels. This is because the production of cassava products is mainly at household level, employing little or no mechanization, resulting in an inability to meet the quality and quantity demand of the industry and other users of the product. Prominent among other factors are; high post harvest losses and low export of cassava products, (Onwulalu, 2007).

Nigeria, though the world leader in cassava production, is not an active participant in cassava trade in the international markets due to the uncompetitive nature of its production and weak processing systems (FAO, 
2006). Hence, cassava is not competitive in 2005; Oke etal., 2005). terms of price of production. That is, the price at which the farmers (producers) that produce the cassava roots sell it at their farm -gates and local areas in their communities is low compared to the price that gari processors sell the cassava products. This is because they would have added the cost of some other factors used during the cost of processing and that is why this study would assess the profit of the farmers being the producers and compare same with those of the processors. Farmers would have preferred to process the cassava roots themselves but due to the high cost of modern processing equipment needed for the processing and high perishability of cassava roots (even before processing) and thus, for this reason, farmers are limited to production only (planting).

Globally speaking, Nigeria is producing at double the price countries like Thailand and China are producing for several reasons. For example, those countries subsidize the costs of energy and raw materials. Unless, Nigerian farmers also have such subsidies, we cannot globally compete in terms of price (Tewe, 2007).

A serious competition exists between the livestock feed industry and other channels in the food chain (especially man) over conventional feed ingredients such as Maize and Soya bean. This had resulted in the high cost and scarcity of these conventional feedstuffs. Poultry feed producers are thus faced with the task of finding alternative feedstuffs that will not compromise quality. The search of such alternatives has been a concern for animal nutritionists in Nigeria for over a decade (Onyimonyi and Okeke, 2005; Onyimonyi and Onukwufor, 2003; Onyimonyi and Okeke, 2002; Tuleun et al.,
Such alternative feedstuffs as cassava peel do not have any direct food requirement by man. They are waste and even constitute health hazards and nuisance in waste disposal of these industries. Since these peels could make up to $10-20 \%$ of the wet weight of the roots, they constitute an important potential resource for animal feeds, if properly processed by a bio-system. Research results indicate that, cassava peel if properly processed can constitute up to $40 \%$ of the diets of rabbits (Omole and Sonaiya, 1981). Also, the ever-increasing competition for cereal in the human diets and livestock industries in tropical African countries makes it imperative to explore the potentials of cassava roots as a suitable cost effective replacement for maize, rice, sorghum and wheat (The comet, 2002).

However, the transformation of cassava waste into various forms for food, feed, and industrial raw material has the potential to help developing countries improve food security, create additional value in rural settings, generate income and employment and develop a more favourable balance of trade. (Oluwalana, 2011) reported that there are opportunities to utilize agro-processing wastes such as cassava peels to generate wealth. The wealth so generated from wastes can lead to reduction of poverty among the rural entrepreneur especially the women processing herbal soap in particular. This concept is called the "waste to wealth" initiative to improve the economic and health status of the beneficiaries.

Value Chains encompass the full range of activities and services required to bring a product and/or service from its production/ conception to its end use. These include the final markets into which a product or service 
is sold; local, national, regional or global. Actors in the value chain are driven by incentives namely, profit, prices, commissions or some other extrinsic factor. It is the incentive in the value chain that encourages private sector investments and oils the wheel of progress for any industry. For the success in global markets, Value Chains must move a product from production to the consumer more efficiently, with better quality and/or in a unique variation different to Value Chains in competing countries. The competitiveness of the Nigerian cassava industry therefore depends on its ability to develop, and to maintain an edge over market rivals.

This article examines the Enterprise assessment across cassava peels value chain in Ogun State Nigeria.

\section{METHODOLOGY}

\section{The study area}

Ogun state is located in the south - western Nigeria and was created in 1976 by the then Federal Military Government from the old western region. It is located within latitudes $3030^{\prime} \mathrm{N}-4030^{\prime} \mathrm{N}$ and longitudes 6030'E7030E (Ogun State Annual Report, 2000). The state has a total of 20 Local Government Areas. Ogun State is bounded in the west by the republic of Benin, in the south by Lagos State and the Atlantic Ocean, in the east by Ondo State and in the North by Oyo State. Ogun State covers a land area of 16,762 square kilometres with a population of 3,728,098 (2006 population census). The Ogun State Agricultural Development Programme (OGADEP) has divided the State into four zones (Abeokuta, Ijebu-Ode, Ikenne and Ilaro) based on geographical spread and administrative convenience.

\section{Sample Size and Sampling Techniques}

Information on this study was obtained from primary source of data. The primary data was collected through structured questionnaire from the main actors of cassava peels enterprise across the value chain such as cassava processors and marketers. Multistage random sampling technique was used to select 180 cassava based processors and marketers in the study area. This involved four stages, the first stage, involved the purposive selection of two zones from the four zones of the Ogun State Agricultural Development project (OGADEP) namely Abeokuta and Ijebu zones. This was done because of the predominance of cassava based farming and processing in these zones. (Elegbede, et al., 2018). In the second stage, six blocks were proportionately selected from the two zones; three blocks from Abeokuta zone with a total of 6 blocks and three blocks from Ijebu zone with a total of 6 blocks. The third stage involved a simple random sampling of two cells from each block and this makes a total of twelve cells in all. Finally, a random selection of nine processors and six marketers from each cell resulting in a total of 180 respondents.

\section{Methods of Data Analysis}

The study data were analysed using descriptive statistics, budgetary technique, and stochastic frontier analysis and the cost function analysis. Frequencies, percentages and mean were used to describe socio - economic variables such as age, sex, educational level, years of experience, potential buyers of cassava peels and utilization potentials in processing and marketing of cassava peels. The gross margin analysis was used to determine the profitability of processing and marketing cassava peels. The stochastic frontier analysis based on the works Coelli (1995) was used to estimate coefficients of the parameters of production function and to analyse the eco- 
nomic efficiency of processing cassava peel theoretical framework are common in literain Ogun State Nigeria. The theoretical ture (Coelli, 1995).

model underlying the analysis includes the Model Specification: technical efficiency and allocative efficiency. The relationship of the previously mentioned model will give us the overall performance measure which is the economic efficiency of processing cassava peels in the study area. Detailed specifications of the

\section{Gross Margin Analysis}

The gross margin for an average processor and marketer of cassava peel was calculated and compared as the difference between the total revenue and total variable cost. The mathematical equation is given below;

$$
G M_{i}=T R_{i}=T V C_{i}
$$

Where $i$ is the number of processors and marketers from $i$.......n

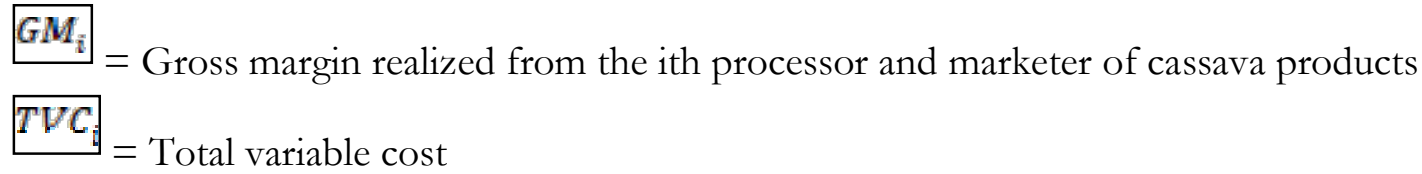

$T R$

$=$ Total revenue

$T R_{i}=P_{i} Q_{i}$

$P$

$=$ price per unit of output $(\mathbb{N})$

$Q_{\mathbf{i}}=$ Output $(\mathrm{kg})$

$N P=G M_{i}=T R_{i}=T C_{i}$

\section{Depreciation}

The straight line depreciation method was used to calculate the depreciation cost of the equipment (fixed assets such as baskets, trays, bags, sieves etc.) used in cassava peels value chain in the study area.

Annual depreciation $=\frac{n}{n-3}$

Where $P p=$ purchase price, $\mathrm{S}=$ Salvage value, $\mathrm{n}=$ no of years of useful life of the asset.

\section{Measures of financial outcome}

The returns per naira invested and operating ratios were used to determine and compare the measure of financial outcome of the cassava peels value chain actors in the study area. They were calculated using the formula below: 


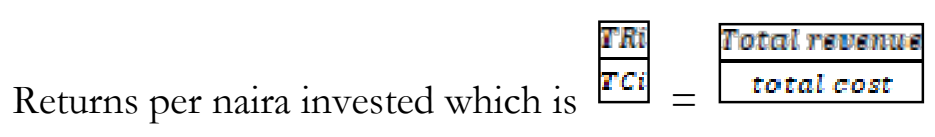

Operating ratio which is $\frac{T C \text { TRi }}{\text { TRi }}=$\begin{tabular}{|c|}
\hline Total cost \\
\hline total revenue \\
\hline
\end{tabular}

All these determine the profitability and financial level of production.

\section{Stochastic Frontier Production Model}

For the purpose of analyzing the economic efficiency of cassava peels to various useful consumer products in the study area, the stochastic frontier production function model for estimating value chain level technical efficiency is specified as: following Amaza and Olayemi (2001):

$\mathrm{Yi}=\mathrm{f}(\mathrm{Xi} ; \beta)+\varepsilon_{\mathrm{i}}=1,2, \ldots \ldots \ldots \mathrm{n}$

Here Yi is output, $\mathrm{Xi}$ denotes the actual input vector, $\beta$ is vector of parameters to be estimated/production function and $\varepsilon_{i}$ is the error term that is composed of two elements, that is: $\varepsilon_{\mathrm{i}}=\mathrm{V}_{\mathrm{i}}-\mathrm{U}_{\mathrm{i}}$

Where $\mathrm{Vi}$ is the symmetric disturbances assumed to be identically, independently and

$\sigma^{2}=\sigma^{2}{ }_{u}+\sigma^{2}$

Furthermore, $\gamma=\sigma^{2} \mathrm{u}$

$\sigma^{2}$

The variance ratio parameter $\gamma$ (Gamma) according to Dawson and Lingard (1991) is represented as below; $\gamma=(0 \leq \gamma \leq 1)$.

The variance ratio parameter $\gamma$ has two important characteristics:

i. When $\sigma^{2}$ tends to zero, then $\mathrm{u}$ is the predominant error in equation (1) and $\gamma$ tends to 1 , implying that the output of the sampled farmers differs from the maximum output mainly because of difference in technical efficiency. normally distributed as $\mathrm{N}\left(0, \sigma^{2}{ }_{\mathrm{v}}\right)$ given the stochastic structure of the frontier. The second component $\mathrm{Ui}$ is a one-sided error term that is independent of $\mathrm{V}$ and is normally distributed as $\left(0, \sigma^{2} \mathrm{u}\right)$, allowing the actual production to fall below the frontier but without attributing all short falls in output from the frontier as inefficiency.

ii. When $\sigma^{2}$ u tends to zero, then the symmetric error $\mathrm{v}$ is the predominant error in equation (1) and so $\gamma$ tends to 0 . Thus based on the value of $\gamma$, it is possible to identify whether the difference between a farmer's output and the efficient output is principally due to random errors ( $\gamma$ tends to 0 ) or the inefficient use of resources ( $\gamma$ tends to 1$)$ (Kalirajan, 1981).

Following Belbase and Grabwoski (1985), the technical efficiency estimation is given by 
the mean of the conditional distribution of fined by: inefficiency term Ui given $\varepsilon_{i}$ and thus de-

$\mathrm{E}\left(\mathrm{U}_{\mathrm{i}} \mid \varepsilon_{\mathrm{i}}\right)=$

$$
\frac{\sigma_{u} \sigma_{v}}{\sigma}\left[\frac{f\left(\varepsilon_{i} \lambda / \sigma\right)}{1-f(\varepsilon, \lambda / \sigma)}-\frac{\varepsilon_{i} \lambda}{\sigma}\right]
$$

here $\lambda=\sigma_{\mathrm{u}}^{2} / \sigma_{\mathrm{v}}^{2}, \sigma^{2}=\sigma^{2}+\sigma^{2}$ while $\mathrm{f}$ and $\mathrm{F}$ represents the standard normal density and cumulative distribution function respectively evaluated at e/a

The farm specific technical efficiency is de-

fined in terms of observed output (Y1) to

$$
\mathrm{TE}=\frac{Y_{1}}{Y_{1} *}=\frac{E\left(Y_{i} \mid u_{i}, X_{i}\right)}{E\left(Y_{i} \mid u_{i}=0, X_{1}\right)}=\mathrm{E}\left[\exp \left(-U_{i} / \varepsilon\right)\right]
$$

Therefore, $\mathrm{TE}=\exp \left(-\mathrm{U}_{\mathrm{i}}\right)$

TE takes values within the interval zero and one (i.e between 0 and 1 ), where 1 indicates a fully efficient farm.

$$
\mathbf{C}_{\mathrm{i}}=\mathrm{g}\left(\mathrm{Y}_{\mathrm{i}}, \mathrm{P}_{\mathrm{i}} ; \alpha\right)+\varepsilon_{\mathrm{i}} \quad \mathrm{i}=1,2, \ldots \ldots \ldots \mathrm{n}
$$

Where $C_{i}$ represents total production cost, $Y_{i}$ represents output produced, $P_{i}$ represents prices of inputs, $\mathrm{C}_{\mathrm{i}}$ represents the parameters of the cost function and $\varepsilon_{i}$ represents the error term that is composed of two elements, that is:

$\varepsilon_{\mathrm{i}}=\mathrm{V}_{\mathrm{i}}+\mathrm{U}_{\mathrm{i}}$

Here $V_{i}$ and $U_{i}$ are as defined earlier. However because inefficiencies are assumed to
The stochastic frontier cost functions model for estimating farm level overall economic efficiency is specified as:

always increase costs, error components have positive signs Sharma, Pingsun, and Halina (1999).

The farm specific economic efficiency (EE) is defined as the ratio of minimum observed total production cost $\left(\mathrm{C}^{*}\right)$ to actual total production cost $(\mathrm{C})$ using the result of equation 6 above. That is:

$$
\mathrm{EE}=\frac{C_{i}}{C_{i} *}=\frac{E\left(C_{i} \mid u_{i}=0, Y_{i} P_{t}\right)}{E\left(Y_{i} \mid u_{i}, Y_{i} P\right)}=\mathrm{E}[\exp (-U i \mid \varepsilon)]
$$


Here EE takes values between $\mathrm{O}$ and $1 . \quad$ peels in the study area.

Hence a measure of farm specific allocative efficiency (AE) is thus obtained from technical and economic efficiencies estimated as:

$\mathrm{AE}=\frac{\mathrm{EE}}{\mathrm{TE}}$

This means that $0 \leq \mathrm{AE} \leq 1$

\section{Technical Efficiency (TE)}

The technical efficiency of the ith sample processor of cassava peels in the study area is the relationship between total output of dry cassava peels and the inputs used in processing.

Stochastic Frontier Production Function The estimation of the stochastic frontier was Analysis

The stochastic frontier production function analysis based on Coelli (1995) was used to estimate coefficients of the parameters of the production function and to analyse the economic efficiency of processing cassava accomplished by maximum likelihood estimation (MLE) according to Ali and Flin (1989). The processing technology of the processors of cassava peels in the study area was specified by the following function;

$Y i=\beta 0+\beta_{1} X_{1}+\beta_{2} X_{2}+\beta_{3} X_{3}+\beta_{4} X_{4}+E i$

Where $\mathrm{Yi}=$ total output of dry cassava peels $(\mathrm{kg})$

$\mathrm{X}_{1}=$ labour in mandays $(\mathrm{N})$

$\mathrm{X}_{2}=$ quantity of fresh cassava peels $(\mathrm{kg})$

$\mathrm{X}_{3}=$ depreciation (

$\beta_{0}=$ constant

$\beta$ 's $=$ parameters to be estimated

$\mathrm{e}=$ error term

\section{Allocative Efficiency}

The allocative or price efficiency of the processors of cassava peels was analyzed using the Stochastic Production Frontier. According to Adekoya (2011), Cobb - Douglas Cost Frontier for processors of cassava peels in the study area is presented explicitly as:

$\Pi^{*}=\varphi_{0}+\varphi_{1} \mathrm{P}_{1}+\varphi_{2} \mathrm{P}_{2}+\varphi_{3} \mathrm{P}_{3}+\varphi_{4} \mathrm{P}_{4}+\left(\mathrm{V}_{\mathrm{it}}-\mathrm{U}_{\mathrm{it}}\right)$

Where:

$\Pi^{*}=$ Normalised profit in naira per processor (defined as the revenue less variable cost normalized

by the price of cassava peels output).

$\mathrm{P}_{1}=$ price of packaging normalized by price of cassava peels per processor (

$\mathrm{P}_{2}=$ Price of labour normalized by price of cassava peels per processor ( 
ELEGBEDE, V. A. OLUWALANA E.O.A. AND SHITTU A.M

$\mathrm{P}_{3}=$ Price of sieve normalized by price of cassava peels per processor (

$\mathrm{P}_{4}=$ depreciated capital items (

$\varphi_{0}=$ constant

$\varphi$ 's $=$ parameters to be estimated

Vit $=$ random errors which covers random effects on the production outside the control

of the processors decision unit.

Uit $=$ allocative inefficiency

\section{Technical and Allocative Inefficiency}

Technical and allocative inefficiency effects is the result of behavioural factors which could be controlled by efficient management (Coelli and Battase, 1996) They are assumed to be independent of the error term.

The estimated technical and allocative inefficiency model is presented explicitly by

$\mu \mathrm{i}=\delta_{0}+\delta_{1} Z_{1}+\delta_{2} Z_{2}+\delta_{3} Z_{3}+\delta_{4} Z_{4}+\delta_{5} Z_{5}+\delta_{6} Z_{6}$

Where:

$\mu \mathrm{i}=$ inefficiency effect

$\delta=$ a vector of unknown parameters to be estimated

$\mathrm{Z}_{\mathrm{i}}=(\mathrm{I}=1,2,3,4,5,6)$ Factors contributing to inefficiency

$\mathrm{Z}_{1}=$ Age of the processors in years

$\mathrm{Z}_{2}=$ Educational level

$Z_{3}=$ Years of experience in cassava peels processing

$\mathrm{Z}_{4}=$ Access to credit (access 1; 0 otherwise)

$\mathrm{Z}_{5}=$ Household size

$\mathrm{Z}_{6}=$ membership of cooperative society

\section{Economic Efficiency (EE)}

The Economic Efficiency is the overall performance measure of processing cassava peels in the study area. The economic efficiency of processing cassava peels was analysed using the relationship below

$\mathrm{EEi}=\mathrm{TE} \times \mathrm{AE}$

Where:

$\mathrm{EEi}=$ Economic efficiency 
$\mathrm{AE}=$ Allocative (cost) efficiency

$\mathrm{TE}=$ Technical efficiency

RESULTS AND DISCUSSION Socioeconomic Characteristics of the Sampled Respondents

The result of the socioeconomic characteristics of actors of cassava peels enterprise across the value chain considered in this study is presented on Table 1 below and it revealed that the mean age of the cassava peel value chain actors was 44 years and 38 years for processors and marketers respectively. Also $77.9 \%$ and $81.2 \%$ of processors and marketers are aged below 50 years. This implies that majority of the value chain actors are in their economically active age. In addition, $60.2 \%$ of the processors and $51.4 \%$ of the marketers had secondary education. In terms of sex, the study revealed that $15.7 \%$ are male while $84.3 \%$ are female for processors of cassava peel while for marketers of cassava peel $28.3 \%$ are male and $52.8 \%$ are female respectively. The result revealed that majority of the actors in cassava peel value chain in the study area are female and this may be due to the fact that women are predominant in processing and marketing of agricultural produce while the males are basically into food crop production. In terms of years of experience in the trade, majority of them were very knowledgeable. About $61.9 \%$ of the respondents had at least 6 years of experience in the trade.

The result of the evaluation of costs and returns on Table 2 showed that the average cost of processing cassava peels was $3090.83 \mathrm{k}$ per month while the average cost of marketing processed cassava peels was W6145.96k per month, the gross margin for processing and marketing cassava peels were A9, 347.74k and $¥ 13,666.22 \mathrm{k}$ per month respectively. The estimated profitability ratio revealed that return per naira for processing and marketing cassava peels were 3.97 and 3.20 respectively. The operating ratio for processing and marketing cassava peels were 0.25 and 0.31 respectively. These showed that the two enterprises were profitable to the respondents. 


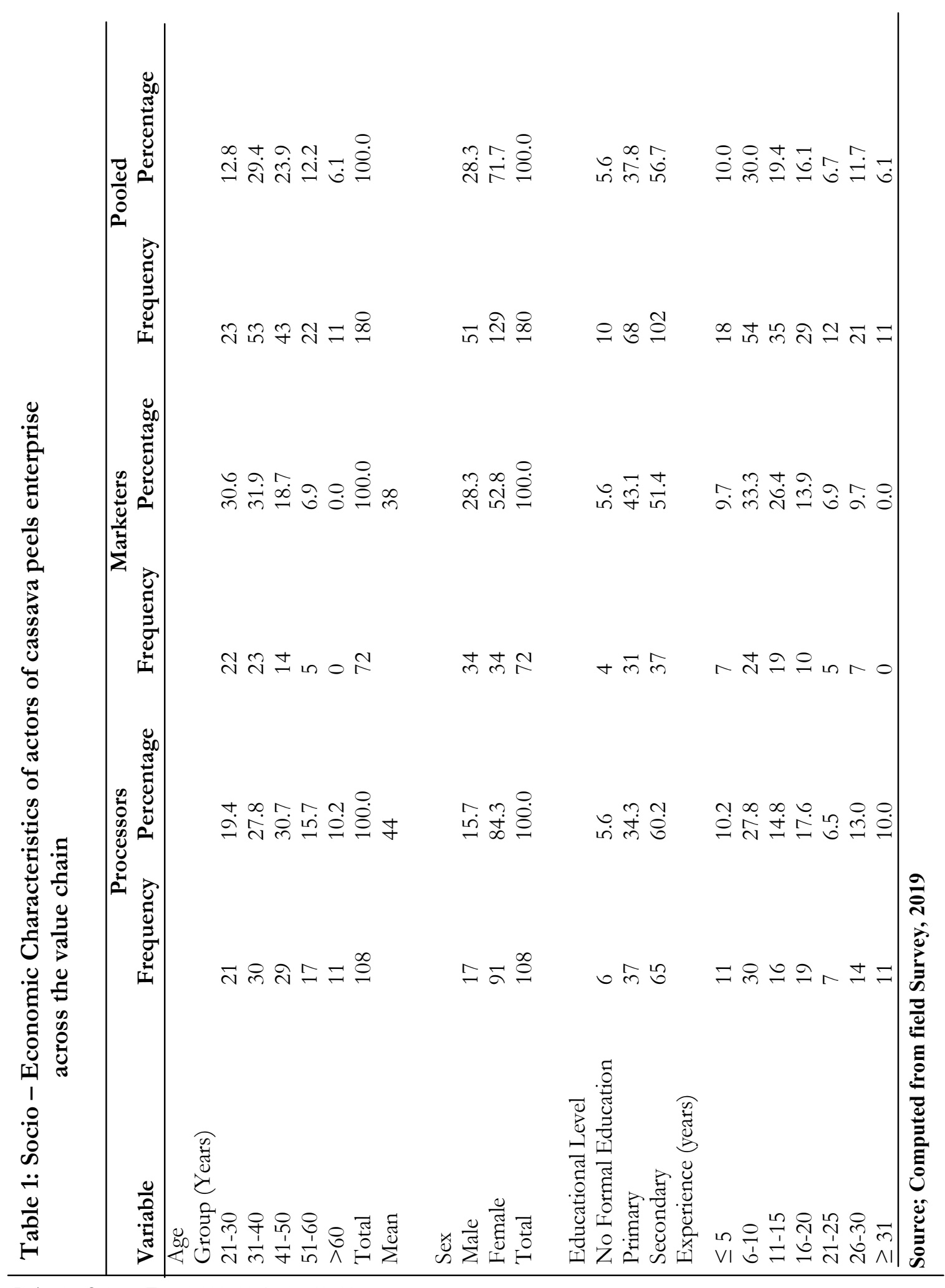

J. Agric. Sci. \& Env. 2020, 20(1 \&2):40-55 
Table 2: Costs and Returns Structure of the Actors of Cassava Peels Enterprise across the Value Chain in $\mathrm{kg} / \mathrm{month} /$ respondent

\begin{tabular}{|c|c|c|c|c|}
\hline \multirow[t]{2}{*}{ Cost and Returns } & \multirow{2}{*}{$\begin{array}{l}\text { Processors } \\
\text { Amount in } \\
\mathrm{N} \text { per } \mathrm{Kg}\end{array}$} & \multirow[t]{2}{*}{$\begin{array}{l}\% \text { of total } \\
\text { Cost }\end{array}$} & \multirow{2}{*}{$\begin{array}{l}\text { Marketers } \\
\text { Amount in } \\
\mathbf{N} \text { per } \mathrm{Kg}\end{array}$} & \multirow[t]{2}{*}{$\begin{array}{l}\% \text { of total } \\
\text { cost }\end{array}$} \\
\hline & & & & \\
\hline $\begin{array}{l}\text { Revenue (N) } \\
\text { Total Revenue (N) } \\
\text { Variable cost items }\end{array}$ & \multicolumn{2}{|l|}{$12,279.00$} & \multicolumn{2}{|l|}{$19,694.00$} \\
\hline Labour cost & 150.00 & 4.85 & - & - \\
\hline Cost of Cassava Peels & - & - & 3523.60 & 57.33 \\
\hline Cost of Transportation & 1233.01 & 39.89 & 1890.86 & 30.76 \\
\hline Cost of Drying & 1037.10 & 33.55 & - & - \\
\hline Packaging Cost & 261.15 & 8.45 & 223.61 & 3.64 \\
\hline Storage Cost & - & - & 157.35 & 2.56 \\
\hline Bagging Cost & 250.00 & 8.09 & - & - \\
\hline $\begin{array}{l}\text { Market Tax charge } \\
\text { Total Variable cost (A) } \\
\text { Fixed Cost Items }\end{array}$ & - 2931.26 & - & $\begin{array}{l}232.36 \\
6027.78\end{array}$ & 3.78 \\
\hline $\begin{array}{l}\text { Sundry Material (Fixed } \\
\text { cost) }\end{array}$ & 159.57 & - & 118.18 & \\
\hline Total Fixed Cost $(\mathbb{N})$ & 159.57 & 5.16 & 118.18 & 1.92 \\
\hline Total Cost (TC) (N) & 3090.83 & 100.00 & 6145.96 & 100.00 \\
\hline Gross Margin & $9,347.74$ & & $13,666.22$ & \\
\hline \multicolumn{5}{|l|}{ Profitability Ratios } \\
\hline Return on investment & 3.97 & & 3.20 & \\
\hline Operating ratio & 0.25 & & 0.31 & \\
\hline
\end{tabular}

Source; Computed from field survey, 2019.

The Stochastic Frontier Production, sors of cassava peels revealed that only DeCost and Efficiency Analysis of Process- preciation on capital $\left(\mathrm{X}_{3}\right)$ have positive relaing Cassava Peels tionship with total output. The result also The result on Table 3 which showed that the parameter estimates obtained from the Maximum Likelihood Estimate for processhowed that Labour $\left(\mathrm{X}_{1}\right)$ and Quantity of cassava peel $\left(\mathrm{X}_{2}\right)$ have negative relationship with output and significantly influence it at 
$(\mathrm{P}<0.01)$ respectively. The negative signs of from processing cassava peels decrease with the coefficient of labour and quantity of increase in labour and quantity of cassava cassava peels showed that the total revenue peels along the chain.

Table 3: The Stochastic Frontier Production Function Results for processing cassava peels along the value chain

\begin{tabular}{lll}
\hline Variable & Regression coefficient & T value \\
\hline Production function & & \\
Constant & $5.56^{* * *}$ & 62.2 \\
& $(0.0894)$ & \\
Cost of labour $\mathrm{X}_{1}$ & $-0.0370^{* * *}$ & -3.57 \\
& $(0.0379)$ & \\
Quantity of cassava peels $\mathrm{X}_{2}$ & $-0.3071^{* * *}$ & -8.10 \\
& $(0.0652)$ & \\
Depreciation $\mathrm{X}_{3}$ & 0.0041 & 0.517 \\
& $(0.0079)$ & \\
\hline
\end{tabular}

Source; Computed from field survey, 2019.

The results of the inefficiency model revealed on table 4 showed that the efficiency of producing dried cassava peels increased with increase in age $(\mathrm{P}<0.01)$, credit access $(\mathrm{P}<0.01)$, household size $(\mathrm{P}<0.01)$ and membership of cooperative society $(\mathrm{P}<0.01)$. Credit access, household size and membership of association are significant at
$1 \%$ and tend to negatively influence the efficiency of cassava processing in the study area. The negative sign of these parameters implies that the higher the access to credit, larger household size and membership to an association the more efficient the processor becomes. 
Table 4: Inefficiency Model

\begin{tabular}{lll}
\hline Constant & $\begin{array}{l}-8.59^{* * *} \\
(0.978)\end{array}$ & -8.79 \\
\hline Age $\left(\mathrm{D}_{1}\right)$ & $-0.168^{* * *}$ & -14.57 \\
& $(0 . .0115)$ & \\
Education level $\left(\mathrm{D}_{2}\right)$ & $0.124^{* * *}$ & 2.19 \\
& $(0.056)$ & \\
Years of experience $\left(\mathrm{D}_{3}\right)$ & $0.0751^{* * *}$ & 3.76 \\
& $(0.0199)$ & \\
Credit access $\left(\mathrm{D}_{4}\right)$ & $-1.24^{* * *}$ & -3.126 \\
& $(0.3955)$ & -6.223 \\
Household size $\left(\mathrm{D}_{5}\right)$ & $-0.590^{* * *}$ & \\
& $(0.0948)$ & -11.77 \\
Membership of Association $\left(\mathrm{D}_{6}\right)$ & $-6.64^{* * *}$ & \\
& $(0.564)$ & \\
Diagnoistic Statistics & & \\
Sigma-squared $\left(\delta^{2}\right)$ & $0.188^{* * *}$ & 6.36 \\
& $(0.2968)$ & \\
Gamma $(\gamma)$ & $0.996^{* * *}$ & 466.69 \\
& $(0.00213)$ & \\
\hline
\end{tabular}

*** implies significance at 1 percent, ** implies significance at 5 percent while * implies significance at 10 percent. Figures in parenthesis are standard errors.

Source: Computed from field survey, 2019

The mean technical efficiency of processors of cassava peels was estimated to be 0.94 . The mean output of 94 percent revealed that there is the potential for the cassava peels processors to increase their output by 6 percent under the present technology along the cassava waste value chain. More so, the mean allocative efficiency of 83 percent for the cassava peels processors along the chain revealed that there is room for 17 percent improvement in their output. Finally, the mean economic efficiency of 78 percent for the cassava waste (peel) processors implies that there is room for improvement by 22 percent and that there was a great potential for increasing the gross output and profit with the existing level of technology along chain. 
ELEGBEDE, V. A. OLUWALANA E.O.A. AND SHITTU A.M

Table 5: Distribution of Technical, Allocative and Economic Efficiency of processing cassava peels along the value chain

\begin{tabular}{|c|c|c|}
\hline Class & Frequency & Percentage \\
\hline \multicolumn{3}{|c|}{ Technical Efficiency } \\
\hline$\leq 0.40$ & 8 & 7.4 \\
\hline $0.41-0.50$ & 6 & 5.6 \\
\hline $0.51-0.60$ & 12 & 11.1 \\
\hline $0.61-0.70$ & 14 & 13.0 \\
\hline $0.71-0.80$ & 25 & 23.1 \\
\hline $0.81-0.90$ & 26 & 24.1 \\
\hline$\geq 0.91$ & 17 & 15.7 \\
\hline Total & 108 & 100 \\
\hline Mean & 0.94 & \\
\hline Minimum & 0.057 & \\
\hline Maximum & 0.968 & \\
\hline \multicolumn{3}{|c|}{ Allocative Efficiency } \\
\hline$\leq 0.10$ & 41 & 38.0 \\
\hline $0.11-0.20$ & 27 & 25.0 \\
\hline $0.21-0.30$ & 15 & 13.9 \\
\hline $0.31-0.40$ & 10 & 9.3 \\
\hline $0.41-0.50$ & 6 & 5.6 \\
\hline$\geq 0.51$ & 9 & 8.3 \\
\hline Total & 108 & 100 \\
\hline Mean & 0.83 & \\
\hline Minimum & 0.018 & \\
\hline Maximum & 0.996 & \\
\hline \multicolumn{3}{|c|}{ Economic Efficiency } \\
\hline$\leq 0.10$ & 46 & 42.6 \\
\hline $0.11-020$ & 36 & 33.3 \\
\hline $0.21-0.30$ & 15 & 13.9 \\
\hline $0.31-0.40$ & 4 & 3.7 \\
\hline$\geq 0.41$ & 7 & 6.5 \\
\hline Total & 108 & 100 \\
\hline Mean & 0.78 & \\
\hline Minimum & 0.0012 & \\
\hline Maximum & 0.6779 & \\
\hline
\end{tabular}

Source; Computed from field survey, 2019.

\section{CONCLUSION AND RECOMMENDATION}

The result of the study revealed that majority of processors and marketers of cassava peels are female. In addition, the mean age of the actors of cassava peels enterprise across the value chain was discovered to be 44 years for processors and 38 years for marketers. Among the potential buyers of cassava by product (peels), goat farmers consti- 
tute $31.1 \%$. Also, it reveals that majority $(45.55 \%)$ of the respondents preferred the Utilization technology to establish cottage industry to process cassava peels into animal feeds, mushrooms production (fertilizers) and herbal soap production. This suggests that effort should be geared towards the development of the utilization technology to establish cottage industry to process cassava by products (peels) into animal feeds, mushrooms production (fertilizers) and herbal soap production. The result of the budgetary analysis revealed that marketing cassava peel is more profitable for marketers than processors. Furthermore, the stochastic frontier analysis revealed that labour and quantity of cassava peels increases the output of the processed cassava peels. The inefficiency model revealed that the efficiency of producing dried cassava peels increased with increase in age $(p<0.01)$, credit access $(p<0.01)$, household size $(p<0.01)$ and membership of cooperative society $(p<0.01)$. The mean technical efficiency of processing cassava peels was estimated to be 0.94 . The mean output of $94 \%$ revealed that there is the potential for processors of cassava peels to increase their output by $6 \%$ under the present technology along the cassava peels value chain. However, the mean allocative efficiency of $83 \%$ for the cassava peels processors along the chain revealed that there is room for $17 \%$ improvement in their output. More so, the mean economic efficiency of $78 \%$ for processing cassava peel implies that there is room for improvement by $22 \%$ and that there is a great potential for increasing the gross output and profit with the existing level of technology along chain. The result concludes that processors of cassava peels are economically efficient along the value chain in the study area.
Based on the findings of this study, it was recommended that there should be a deliberate effort by all stakeholders to encourage and promote value chain addition to cassava peels. Processors and marketers of cassava peels should be encourage to participate in educative programmes such as seminars, workshop and trainings to educate them on the importance of the value chains of cassava peels in order to increase the utilization potentials to generate income and reduce unemployment. More so, Awareness should be created for existing and prospective entrepreneurs about business opportunities in utilizing cassava peels generated during commercial processing for making value added products like herbal soap, animal feeds and mushroom cultivation. Government and private organization should encourage the development of appropriate methods and technologies for growing mushrooms, for turning cassava peel into animal feed suitable (goats) and herbal soap production from cassava peel.

Findings from the study revealed that the marketers of cassava peel are more profitable than the processors in terms of their gross margin. Therefore, government and the masses especially the rural farmers should be encouraged into marketing of cassava peels so as to generate more income and thereby alleviate poverty from their homes. Processors and marketers of cassava peels in the study area should therefore be encouraged to form cooperative groups and have access to credit from banks where they can obtain better capital base for higher output. Also, government should invest more in making credit available to farmers and processors at low interest rate and without collateral so that they can maximize the profit generated from the cassava peels and reduce production inefficiencies. 


\section{REFERENCES}

Adebayo, K.J, Dipeolu, A.O., Ayinde, I.A 2008 Analysis of cassava food products Demand in Lagos. The Journal of Developing Areas 41 (2): 109 - 118. Published by Tennese State University, USA. Spring 2008.

Coelli, T.J. 1995. Recent Development in frontier modelling and efficiency measurement. Australian Journal of Agricultural Economics, 39 (1) : 219- 245.

Coelli, T.J., G.E. Battese 1996. Identification of factors which influence the Technical Inefficiency of Indian Farmers. Australian Journal of Agricultural and Resource Economics. 40 (2):103 - 128.

FAO 1992. Population, Education and $\mathrm{Nu}-$ trition: version for Africa, Rome.

FAO 2007. The state of Food and Agriculture: version for Africa, Rome.

FAO 2006. Production Yearbook. FAOstat Data Base. Consulted August, 2008.

FAOSTAT 2010. Food, Nutrition and Food Security : Version for Africa, Rome.

Oluwalana, E.O 2011. Economic Potential of Forest - Based Small - Scale Enterprises in Herbal Soap Processing and Marketing in South - West Nigeria. Pp: 14-15, 281-282.

Omole, I.A., E.B. Sonaiya, 1981. The effect of protein source and methionine supplementation on cassava Peel utilization by growing rabbits. Nutr. Rep. Int., 23: 729737.
Onyimonyi, A.E., G.C. Okeke 2002. Performance of weaner pigs fed varying dietary level of Bambara (Voandzeria subterrenea Thouars) waste. Proceedings of 7 th Annual Conference of Animal Scientist Association of Nigeria (ASAN), Pp :24 -28.

Onyimonyi, A.E., G.C. Okeke 2005. Carcass, Organ and Pathological characteristics of grower pigs fed cassava peal meal. Agroscience Journal of Agriculture Food and Environment Ext., 1: 1-4.

Onyimonyi, A.E., J.O. Onukwufor (2003). Effect of toasted Bambara (Voandzeia subterrenea Thouars) waste on Performance of growing pullets. Proceeding of the $28^{\text {th }}$ Annual Conference of the Nigerian Society For Animal Production (NSAP). 16th-20th March, pp: 237-239.

Onwulalu, A.P 2007. Nigeria tackles cassava production, processing and marketing issues. Sunday, April 29, 2007.

Smith, O.B 1988. A review of ruminant responses to cassava - based diets. In Hahn, S.K and Reynolds, L. (2012) Animal Feed Resources Information system. Feedipedia.

Tewe, O 2007. Nigeria Tackles Cassava Production, Processing and Marketing issues. Sunday Punch, April 29, 2007.

Tuleun, C.C., M.C. Njike, S.A. Ikurior N.G. Ehiobu 2005. Replacement of Maize with Cassava Root Meal/Brewers Yeast Slurry in the diets of Broilers. Proceeding of the 30th Annual Conference of the Nigerian Society for Animal production (NSAP).

(Manuscript received: 21st August, 2017; accepted: 11th March, 2020). 